\title{
Histoplasmosis among hospitalized febrile patients in northern Tanzania
}

\author{
Sarah M. Lofgren ${ }^{a}$, Emily J. Kirsch ${ }^{b}$, Venance P. Maro ${ }^{c, d}$, Anne B. Morrissey ${ }^{a}$, \\ Levina J. Msuya ${ }^{c, d}$, Grace D. Kinabo ${ }^{c, d}$, Wilbrod Saganda ${ }^{e}$, Helmut C. Diefenthal $^{c, d}$, \\ Habib O. Ramadhani ${ }^{\mathrm{c}}$, L. Joseph Wheat ${ }^{\mathrm{b}}$, John A. Crump ${ }^{\mathrm{a}, \mathrm{c}, \mathrm{d}, \mathrm{f}, \mathrm{g}, *}$ \\ a Division of Infectious Diseases and International Health, Department of Medicine, Box 102359, Duke University Medical Center, Durham, NC 27710, USA \\ b Miravista Diagnostics, 4444 Decatur Blvd., Suite 300, Indianapolis, IN 46241, USA \\ c Kilimanjaro Christian Medical Centre, PO Box 3010, Moshi, Tanzania \\ d Kilimanjaro Christian Medical College, PO Box 3010, Tumaini University, Moshi, Tanzania \\ e Mawenzi Regional Hospital, PO Box 3054, Moshi, Tanzania \\ f Department of Pathology, Box 3712, Duke University Medical Center, Durham, North Carolina, USA \\ g Duke Global Health Institute, Box 90519, Duke University, Durham, NC 27708, USA
}

\section{A R T I C L E I N F O}

\section{Article history:}

Received 3 October 2011

Received in revised form 22 May 2012

Accepted 22 May 2012

\section{Keywords:}

Africa

Histoplasmosis

HIV

Tanzania

Tuberculosis

\begin{abstract}
A B S T R A C T
Histoplasmosis may be common in East Africa but the diagnosis is rarely confirmed. We report $9(0.9 \%)$ cases of probable histoplasmosis retrospectively identified among 970 febrile inpatients studied in northern Tanzania. Median (range) age was $31(6,44)$ years, 6 (67\%) were female, 6 (67\%) HIV-infected; 7 (78\%) were clinically diagnosed with tuberculosis or bacterial pneumonia. Histoplasmosis is an important cause of febrile illness in Tanzania but is rarely considered in the differential diagnosis. Increased clinician awareness and availability of reliable diagnostic tests may improve patient outcomes.
\end{abstract}

(C) 2012 Royal Society of Tropical Medicine and Hygiene. Published by Elsevier Ltd. All rights reserved.

\section{Introduction}

Histoplasmosis is known to occur in sub-Saharan Africa but is rarely diagnosed. In settings with limited laboratory capacity, histoplasmosis may be difficult to distinguish from diseases with similar clinical features, such as tuberculosis and bacterial pneumonia. While Histoplasmosis capsulatum var. duboisii (H. duboisii) appears to occur more often in west Africa and Histoplasmosis capsulatum var. capsulatum (H. capsulatum) predominates in southern

* Corresponding author. Division of Infectious Diseases and International Health, Department of Medicine, Duke University Medical Center, Box 102359, Durham, NC 27710, USA. Tel.: +1 919684 2660; fax: +1 9196848902 .

E-mail address: john.crump@duke.edu (J.A. Crump).
Africa, both varieties have been documented to cause human infection in East Africa. ${ }^{1}$

In Tanzania, $H$. duboisii has been isolated from environmental samples ${ }^{2}$ and $H$. capsulatum has been reported to cause human disease in the coastal areas around the cities of Tanga ${ }^{3}$ and Dar es Salaam, ${ }^{1}$ and has been documented in a Tanzanian expatriate. ${ }^{4}$ We report nine human cases of histoplasmosis from northern Tanzania identified by urine or serum antigen testing and highlight the challenge in clinical diagnosis of histoplasmosis in areas with limited laboratory capacity.

\section{Materials and methods}

From August 2007 through September 2008, we enrolled 870 febrile inpatients at Kilimanjaro Christian 
Table 1

Characteristics and laboratory findings, patients with positive urine or serum Histoplasma antigen, northern Tanzania, 2007-8

\begin{tabular}{|c|c|c|c|c|c|c|c|c|c|c|c|c|}
\hline & Age, years & Gender & $\begin{array}{l}\text { HIV status } \\
\text { (CD4 count, \%) }\end{array}$ & $\begin{array}{l}\text { Urine Histoplasma } \\
\text { antigen }(\mathrm{ng} / \mathrm{mL})\end{array}$ & $\begin{array}{l}\text { Serum } \\
\text { Histoplasma } \\
\text { antigen }(\mathrm{ng} / \mathrm{mL})\end{array}$ & $\begin{array}{l}\text { Mycobacterial } \\
\text { blood culture }\end{array}$ & $\begin{array}{l}\text { Aerobic blood } \\
\text { culture }\end{array}$ & $\begin{array}{l}\text { Blood } \\
\text { parasite } \\
\text { smear }\end{array}$ & Laboratory values ${ }^{\mathrm{a}, \mathrm{b}}$ & Chest radiograph & $\begin{array}{l}\text { Provisional and } \\
\text { discharge } \\
\text { diagnosis }\end{array}$ & $\begin{array}{l}\text { Alive at } \\
\text { follow-up }\end{array}$ \\
\hline Patient 1 & 44 & M & $\begin{array}{l}\text { Infected } \\
15,4 \%\end{array}$ & 2.13 & None Detected & Neg & Neg & $\mathrm{Neg}$ & $\begin{array}{l}\text { WBC 3.1, HCT 34.0, } \\
\text { Plts 257, Neut 2.5, } \\
\text { Lym 0.4, Mono 200, } \\
\text { Eos 279, Baso } 19\end{array}$ & $\begin{array}{l}\text { Parenchymal } \\
\text { abnormalities } \\
\text { L lung alveolar } \\
\text { infiltrates } \\
\text { R lung multiple } \\
\text { cavitary lesions }\end{array}$ & $\begin{array}{l}\text { Pneumonia, HIV, } \\
\text { pulmonary TB }\end{array}$ & No \\
\hline Patient 2 & 23 & $\mathrm{~F}$ & Not infected & $<0.6$ & None Detected & Neg & Neg & Neg & $\begin{array}{l}\text { WBC } 1.6, \text { HCT } 14.8 \text {, } \\
\text { Plts } 128 \text {, Neut } 0.3, \\
\text { Lym } 1.2 \text {, Mono } 112 \text {, } \\
\text { Eos } 19 \text {, Baso } 11\end{array}$ & Normal & Anemia, malaria & Yes \\
\hline Patient 3 & 31 & $\mathrm{~F}$ & Not infected & $>39.0$ & $>39.0$ & Contaminated & Neg & Neg & $\begin{array}{l}\text { WBC } 10.5, \text { HCT } 19.2 \text {, } \\
\text { Plts } 36, \text { Neut } 8.7 \text {, } \\
\text { Lym } 7.6 \text {, Mono } 74 \text {, } \\
\text { Eos } 13 \text {, Baso } 74\end{array}$ & $\begin{array}{l}\text { Nodular } \\
\text { abnormalities } \\
\text { micronodules } \\
\text { throughout both } \\
\text { lungs }\end{array}$ & $\begin{array}{l}\text { HIV, pneumonia, } \\
\text { malaria, } \\
\text { gastroenteritis }\end{array}$ & Yes \\
\hline Patient 4 & 39 & M & Not infected & $<0.6$ & $\begin{array}{l}\text { None available } \\
\text { for testing }\end{array}$ & Neg & Neg & Neg & $\begin{array}{l}\text { WBC } 3.0 \text {, HCT } 44.3 \text {, } \\
\text { Plts } 25 \text {, Neut } 1.5 \text {, } \\
\text { Lym 0.7, Mono } 777 \text {, } \\
\text { Eos 3, Baso } 4\end{array}$ & Not done & $\begin{array}{l}\text { Malaria, } \\
\text { typhoid, } \\
\text { gastroenteritis }\end{array}$ & Yes \\
\hline Patient 5 & 6 & $\mathrm{~F}$ & $\begin{array}{l}\text { Infected } \\
10,2 \%\end{array}$ & 4.01 & $\begin{array}{l}\text { None available } \\
\text { for testing }\end{array}$ & Not done & Neg & Neg & $\begin{array}{l}\text { WBC } 16.4 \text {, HCT } 29.3 \text {, } \\
\text { Plts } 379 \text {, Neut } 12.1 \text {, } \\
\text { Lym } 3.2 \text {, Mono } 853 \text {, } \\
\text { Eos } 131 \text {, Baso } 49\end{array}$ & $\begin{array}{l}\text { Interstitial infiltrates } \\
\text { probably due to } \\
\text { edema } \\
\text { Cardiomegaly }\end{array}$ & $\begin{array}{l}\text { Congestive } \\
\text { cardiac failure, } \\
\text { mitral } \\
\text { regurgitation, } \\
\text { severe } \\
\text { pneumonia }\end{array}$ & Yes \\
\hline Patient 6 & 31 & $\mathrm{~F}$ & $\begin{array}{l}\text { Infected } \\
10,2 \%\end{array}$ & $>39.0$ & $>39.0$ & Neg & Neg & Neg & $\begin{array}{l}\text { WBC } 2.4 \text {, HCT } 29.7 \text {, } \\
\text { Plts } 299 \text {, Neut } 1.7 \text {, } \\
\text { Lym } 0.5 \text {, Mono } 103 \text {, } \\
\text { Eos } 22 \text {, Baso } 14\end{array}$ & $\begin{array}{l}\text { Nodular } \\
\text { abnormalities } \\
\text { Both lungs full of } \\
\text { micronodules }\end{array}$ & $\begin{array}{l}\text { HIV, oral } \\
\text { candidiasis, } \\
\text { pulmonary TB }\end{array}$ & Yes \\
\hline Patient 7 & 7 & $\mathrm{~F}$ & $\begin{array}{l}\text { Infected } \\
91,6 \%\end{array}$ & 2.37 & $\begin{array}{l}\text { None available } \\
\text { for testing }\end{array}$ & Not done & $\begin{array}{l}\text { Pos Strep. } \\
\text { pneumoniae }\end{array}$ & Neg & $\begin{array}{l}\text { WBC } 10.2 \text {, HCT } 15.7 \text {, } \\
\text { Plts } 246 \text {, Neut } 6.9 \text {, } \\
\text { Lym } 2.8 \text {, Mono } 510 \text {, } \\
\text { Eos } 0 \text {, Baso } 41\end{array}$ & Not done & $\begin{array}{l}\text { HIV, severe } \\
\text { pneumonia, } \\
\text { pulmonary TB }\end{array}$ & Yes \\
\hline Patient 8 & 36 & M & $\begin{array}{l}\text { Infected } \\
22,3 \%\end{array}$ & $\begin{array}{l}\text { None available for } \\
\text { testing }\end{array}$ & 3.32 & Neg & Neg & Neg & $\begin{array}{l}\text { WBC } 8.4 \text {, HCT } 23.9 \text {, } \\
\text { Plts } 91 \text {, Neut } 7.0 \text {, } \\
\text { Lym } 1.1 \text {, Mono } 311 \text {, } \\
\text { Eos } 0 \text {, Baso } 4\end{array}$ & Normal & $\begin{array}{l}\text { HIV, malaria, } \\
\text { pneumonia }\end{array}$ & No \\
\hline Patient 9 & 33 & $\mathrm{~F}$ & $\begin{array}{l}\text { Infected } \\
8,1 \%\end{array}$ & $\begin{array}{l}\text { None available for } \\
\text { testing }\end{array}$ & $<0.6$ & Neg & Neg & Neg & $\begin{array}{l}\text { WBC } 18.8 \text {, HCT } 28.5 \text {, } \\
\text { Plts } 395 \text {, Neut } 16.0 \text {, } \\
\text { Lym } 0.9 \text {, Mono } 1200 \text {, } \\
\text { Eos } 508 \text {, Baso } 94\end{array}$ & Not done & $\begin{array}{l}\text { HIV, pneumonia, } \\
\text { Kaposi's } \\
\text { sarcoma, } \\
\text { pulmonary TB }\end{array}$ & $\begin{array}{l}\text { Yes, but } \\
\text { died after } \\
\text { follow up } \\
\text { period }\end{array}$ \\
\hline
\end{tabular}

Neg: Negative; Pos.: Positive; Strep.: Streptococcus

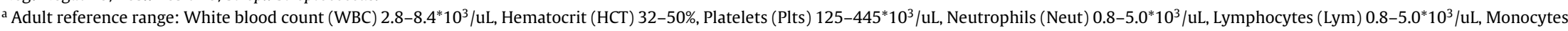
(Mono) 56-840/uL, Eosinophils (Eos) 0-1008/uL, Basophils (Baso) 0-84/uL

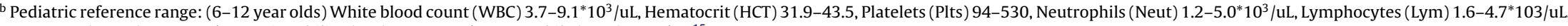
Monocytes (Mono) 100-800/uL, Eosinophilias (Eos) 100-1500/uL, Basophils (Baso) 0-40/uL. ${ }^{15}$ 
Medical Centre and Mawenzi Regional Hospital in Moshi, Tanzania, as part of a study to characterize the etiology of febrile illness. ${ }^{5,6}$ A standardized clinical history and physical examination was done by a member of the research team. Among other diagnostic samples, blood cultures, acute urine, and acute and convalescent serum were collected. After completion of study enrollment and follow up, acute urine and serum samples that had been frozen at $-80^{\circ} \mathrm{C}$ and transported on dry ice were tested retrospectively for Histoplasma antigen using a sandwich enzyme immunoassay (EIA) using polyclonal antibodies to $H$. capsulatum (the MVista Histoplasma capsulatum Quantitative Antigen EIA; Miravista Diagnostics, Indianapolis, IN, USA). Serum specimens were treated with ethylene diamine tetraacetic acid at $104^{\circ} \mathrm{C}$ before testing for antigen. ${ }^{7}$ Specimens yielding a result above the cutoff were regarded as positive. ${ }^{8,9}$ All positive results were confirmed by repeat testing. A case of probable histoplasmosis was defined as a patient with Histoplasma antigen test result from detectable $<0.6 \mathrm{ng}$ to $>39.0 .^{9}$

\section{Results}

Of 870 patients enrolled, 628 (72.2\%) patients had urine available for Histoplasma urine antigen testing. Of these, 7 (1.1\%) were found to be positive with concentrations ranging from $<0.6$ to $>39.0 \mathrm{ng} / \mathrm{mL}$. Of these with Histoplasma antigenuria, 4 also had serum available for testing and $2(50 \%)$ of these also had detectable Histoplasma antigen in their serum. Of those who had urine tested an additional 200 patients ( 100 pediatric and 100 adult) had acute serum tested for Histoplasma antigen. From these samples 2 additional patients were found to have serum positive for Histoplasma antigen. In total, $9(0.9 \%)$ patients met the definition of probable histoplasmosis. All results were confirmed positive on repeat testing. No patient had a positive blood culture for H. capsulatum (Table 1 ). Histoplasma testing was done 6-18 months after sample collection. Once available, results were provided to the clinical team.

\section{Discussion}

We demonstrate that Histoplasma is an etiologic agent of fever among inpatients with and without HIV infection in northern Tanzania. ${ }^{5,6}$ However, histoplasmosis was not considered in the differential diagnosis by clinicians and without the laboratory capacity to support histoplasmosis diagnosis, patients with probable histoplasmosis were often diagnosed clinically with tuberculosis, bacterial pneumonia, or malaria. The majority of patients with histoplasmosis were treated for other causes of disease based on perceptions of common etiologies for clinical syndromes. Improved awareness of the presence of histoplasmosis may lead to incorporation of the infection in differential diagnosis, particularly among persons not responding to empiric treatment for tuberculosis, community-acquired pneumonia, and malaria.

The diagnosis of histoplasmosis in this study was by antigen testing. While we collected blood cultures on all participants, blood culture techniques that would reliably detect Histoplasma fungemia ${ }^{10}$ were only used among adults and adolescents. In all cases Histoplasma antigen testing was reproducibly positive. The sensitivity of the Histoplasma antigen test among HIV-infected patients is $100 \%$ in urine and $92.3 \%$ in serum, and the specificity of both is $99 \%$ among controls. ${ }^{7,9}$ Detection of antigen is a basis for a probable diagnosis of histoplasmosis in patients with compatible clinical findings. ${ }^{11}$ While it is uncertain whether our patients had $H$. capsulatum or $H$. duboisii, as the antigen detected in both mycoses is cross reactive, ${ }^{12}$ clinical features and other case series done in East Africa suggest that $H$. capsulatum is likely to predominate. ${ }^{3}$

Although Histoplasma has been isolated from patient samples in Tanzania in the past, ${ }^{13}$ none of the patients reported in our series had positive fungal cultures. Consequently, the diagnosis of probable histoplasmosis relied on the combination of antigen detection and clinical features. Future research should focus on identifying culture-confirmed histoplasmosis to allow validation of non-culture diagnostic techniques in the sub-Saharan Africa setting. Adaptation and validation of Histoplasma antigen tests for use in low resource settings could assist with recognition of patients with the infection. ${ }^{14}$

In conclusion, histoplasmosis is a cause of fever among inpatients in northern Tanzania but is rarely considered by clinicians in settings with limited laboratory capacity. Patients with histoplasmosis often receive a clinical diagnosis of tuberculosis, bacterial pneumonia or malaria leading to inappropriate treatment. Improved access to diagnostic tests for histoplasmosis, including the development of an appropriately validated simple Histoplasma antigen test suitable for use in low- and middle-income countries where histoplasmosis is endemic may improve patient outcomes.

Authors' contributions: JAC, ABM, and LJW conceived the work; VPM, LJM, GDK, WS, and HOR were responsible for the clinical data collection; HCD read chest radiographs; ABM coordinated processing, archiving, and shipping of laboratory samples; EJK and LJW conducted and interpreted Histoplasma laboratory work; SML compiled and analyzed data and wrote the first draft of the manuscript. All authors contributed to the revision of the manuscript and read and approved the final version. SML and JAC are guarantors of the paper.

Acknowledgements: The authors thank Ahaz T. Kulanga, MBA, for providing administrative support to this study and Pilli M. Chambo, Beata V. Kyara, Beatus A. Massawe, Anna D. Mtei, Godfrey S. Mushi, Lillian E. Ngowi, Boniface N. Njau, Flora M. Nkya, and Winfrida H. Shirima for interviewing and enrolling study participants. We are grateful to the leadership, clinicians and patients of KCMC and MRH for their contributions to this research. We thank Miravista Diagnostics, Indianapolis, Indiana, USA, for performing Histoplasma capsulatum Quantitative Antigen EIA on patient samples. We acknowledge the Hubert-Yeargan Center for Global Health at Duke University for critical infrastructure support for the Kilimanjaro Christian Medical Centre-Duke University Collaboration. 
Funding: This research was supported by an International Studies on AIDS Associated Co-infections (ISAAC) award, a United States National Institutes of Health (NIH) funded program (U01 AI062563). Authors received support from NIH awards ISAAC (ABM, VPM, LJM, GDK, HOR, JAC); AIDS International Training and Research Program D43 PA-03018 (ABM, VPM, HOR, JAC); the Duke Clinical Trials Unit and Clinical Research Sites U01 AI069484 (VPM, JAC), the Duke Center for AIDS Research P30 AI 64518 (L-YY, S-CC); the Center for HIV/AIDS Vaccine Immunology U01 AI067854 (JAC); and the Hubert-Yeargan Center for Global Health at Duke University (SML).

Competing interests: L. Joseph Wheat is Director and Emily J. Kirsch is an employee of Miravista Diagnostics.

Ethical approval: This study was approved by the KCMC Research Ethics Committee, the Tanzania National Institutes for Medical Research National Research Ethics Coordinating Committee, and an Institutional Review Board of Duke University Medical Center.

\section{References}

1. Johnstone G. Histoplasmosis in Tanganyika (Tanzania).J Trop Med Hyg 1965;68:85-91.

2. Al-Doory Y, Kalter SS. The isolation of Histoplasma duboisii and keratinophilic fungi from soils in East Africa. Mycopathol Mycol Appl 1967;31:289-95.

3. Ajello L, Manson-Bahr PEC, Moore JC. Amboni Caves, Tanganyika, a new endemic area for Histoplasma capsulatum. Am J Trop Med Hyg 1960;9:633-8.

4. Mignogna MD, Fedele S, Russo LL, Ruoppo E, Muzio LL. A case of oral localized histoplasmosis in an immunocompetent patient. Eur J Clin Microbiol Infect Dis 2001;20:753-5.
5. Crump JA, Ramadhani HO, Morrissey AB, et al. Invasive bacterial and fungal infections among hospitalized HIV-infected and HIVuninfected children and infants in northern Tanzania. Trop Med Int Health 2011;16:830-7.

6. Crump JA, Ramadhani HO, Morrissey AB, et al. Invasive bacterial and fungal infections among hospitalized HIV-infected and HIVuninfected adults and adolescents in northern Tanzania. Clin Infect Dis 2011;52:341-8.

7. Swartzentruber S, LeMonte A, Witt J, et al. Improved detection of Histoplasma antigenemia following dissociation of immune complexes. Clin Vaccine Immunol 2009;16:320-2.

8. Wheat LJ. MVista ${ }^{\circledR}$ Histoplasma capsulatum Quantitative Antigen EIA. 2009; Available from: http://www.miravistalabs.com/ Files/pdf/Histo_info_Ver_5_2009.pdf [accessed 15 June 2009].

9. Connolly PA, Durkin MM, LeMonte AM, Hackett EJ, Wheat JL. Detection of Histoplasma antigen by a quantitative enzyme immunoassay. Clin Vaccine Immunol 2007;14:1587-91.

10. Crump JA, Morrissey AB, Ramadhani HO, Njau BN, Maro VP, Reller LB. Controlled comparison of BacT/ALERT MB system, manual MYCO/F LYTIC, and ISOLATOR 10 system for detection of Mycobacterium tuberculosis bacteremia. J Clin Microbiol 2011;49:3054-7.

11. De Pauw B, Walsh TJ, Donnelly JP, et al. Revised definitions of invasive fungal disease from the European Organization for Research and Treatment of Cancer/Invasive Fungal Infections Cooperative Group and the National Institute of Allergy and Infectious Diseases Mycoses Study Group (EORTC/MSG) Consensus Group. Clin Infect Dis 2008;46:1813-21.

12. Wheat J, Wheat $\mathrm{H}$, Connolly P, et al. Cross-reactivity in Histoplasma capsulatum variety capsulatum antigen assays of urine samples from patients with endemic mycoses. Clin Infect Dis 1997;24: 1169-71.

13. Archibald LK, den Dulk MO, Pallangyo KJ, Reller LB. Fatal Mycobacterium tuberculosis bloodstream infections in febrile hospitalized adults in Dar es Salaam, Tanzania. Clin Infect Dis 1998;26: 290-6.

14. Scheel CM, Samayoa B, Herrera A, et al. Development and evaluation of an enzyme-linked immunosorbent assay to detect Histoplasma capsulatum antigenuria in immunocompromised patients. Clin Vaccine Immunol 2009;16:852-8.

15. Buchanan AM, Muro FJ, Gratz J, et al. Establishment of haematological and immunological reference values for healthy Tanzania children in the Kilimanjaro Region. Trop Med Int Health 2010;15:1011-21. 